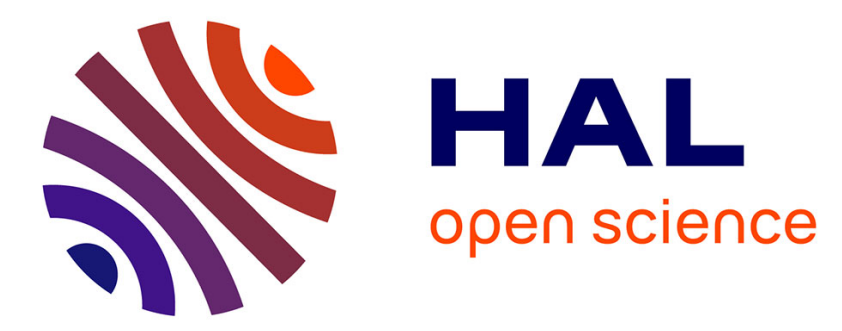

\title{
Modulating ILs' components solubilities in aqueous-ionic liquid biphasic systems: a Q-NMR investigation
}

\author{
Maria Atanassova, Valérie Mazan, Isabelle Billard
}

\section{To cite this version:}

Maria Atanassova, Valérie Mazan, Isabelle Billard. Modulating ILs' components solubilities in aqueous-ionic liquid biphasic systems: a Q-NMR investigation. ChemPhysChem, 2015, 16 (8), pp.1703-1711. 10.1002/cphc.201500071 . hal-02271463

\section{HAL Id: hal-02271463 \\ https://hal.science/hal-02271463}

Submitted on 26 Aug 2019

HAL is a multi-disciplinary open access archive for the deposit and dissemination of scientific research documents, whether they are published or not. The documents may come from teaching and research institutions in France or abroad, or from public or private research centers.
L'archive ouverte pluridisciplinaire HAL, est destinée au dépôt et à la diffusion de documents scientifiques de niveau recherche, publiés ou non, émanant des établissements d'enseignement et de recherche français ou étrangers, des laboratoires publics ou privés. 


\title{
Modulating the solubilities of ionic liquid components solubilities in aqueous-ionic liquid biphasic systems: a Q-NMR investigation
}

\author{
Maria Atanassova ${ }^{[\mathrm{a}, \mathrm{b}, \mathrm{c}]}$, Valérie Mazan ${ }^{[\mathrm{a}, \mathrm{b}]}$ and Isabelle Billard ${ }^{[\mathrm{a}, \mathrm{b}, \mathrm{c}, \mathrm{d}, \mathrm{e}]} *$ \\ [a] M. Atanassova, V. Mazan, I. Billard \\ Université de Strasbourg, IPHC, 23 rue du Loess 67037 Strasbourg, (France) \\ [b] M. Atanassova, V. Mazan, I. Billard \\ CNRS, UMR 7178, 67037 Strasbourg, (France) \\ [c] M. Atanassova \\ University of Chemical Technology and Metallurgy, Department of General and Inorganic Chemistry, \\ 8 Kliment Okhridski blvd., 1756 Sofia, (Bulgaria) \\ [d] Univ. Grenoble Alpes, LEPMI, F-38000 Grenoble, (France) \\ [e] CNRS, LEPMI, F-38000 Grenoble, (France) \\ *E-mail: isabelle.billard@lepmi.grenoble-inp.fr
}

Keywords: ionic liquids; biphasic systems; perchlorate ions; Q-NMR

\section{abstract}

Aqueous-ionic liquid (A-IL) biphasic systems have been examined in terms of deuterated water, acid and IL cation and anion mutual solubilities in the upper (waterrich, in mole fraction) and lower phase of aqueous/IL biphasic systems, at ambient temperature. The biphasic mixtures were composed of deuterated acids of various concentrations ( $\mathrm{DCl}, \mathrm{DNO}_{3}, \mathrm{DClO}_{4}$ from $10^{-2}$ to $10^{-4} \mathrm{M}$ mainly) and five ionic liquids of the imidazolium family with hydrophobic anion $\left(\mathrm{CF}_{3} \mathrm{SO}_{2}\right)_{2} \mathrm{~N}^{-}$, viz. $\left[\mathrm{C}_{1} \mathrm{C}_{\mathrm{n}} \mathrm{im}\right]\left[\mathrm{Tf}{ }_{2} \mathrm{~N}\right]$, $\left(\mathrm{n}=2,4,6,8\right.$ and 10). Analytical techniques applied are ${ }^{1} \mathrm{H}$ NMR, ${ }^{19} \mathrm{~F}$ NMR, KarlFischer titration, pH-potentiometry for ILs' cation and anion, water and acid determination, respectively. The effects of ionic strength $\left(\mu=0.1 \mathrm{M} \mathrm{NaCl}\right.$ and $\mathrm{NaNO}_{3}$ as well as $\mu=0.1 \mathrm{M}, 0.2 \mathrm{M}$ and $0.4 \mathrm{M} \mathrm{NaClO}_{4}$ according to the investigated acid), the nature of the IL cation as well as the nature of the mineral acid on the solubilities of $\left(\mathrm{D}_{2} \mathrm{O}, \mathrm{D}^{+}, \mathrm{Tf}_{2} \mathrm{~N}^{-}, \mathrm{C}_{1} \mathrm{C}_{\mathrm{n}} \mathrm{im}^{+}\right)$entities in the lower or upper phases were determined. Addition of sodium perchlorate enhances $\mathrm{Tf}_{2} \mathrm{~N}^{-}$solubility, while it inhibits ILs' cation solubility. Differences in ILs' cation and anion solubilities up to $42 \mathrm{mM}$ have been evidenced. Consequences for aqueous biphasic system characterization, solvent extraction process of metal ions and ecological impact of ILs are discussed.

\section{Introduction}

The aim of green or sustainable chemistry is the development of innovative highly efficient technological processes eliminating hazardous chemicals for man and the environment. The growing awareness of safety and environmental impact related with the use of molecular diluents renders their replacement with less noxious alternatives desirable. ${ }^{[1,2]}$ One of the ideas under study is the replacement of molecular diluents by ionic liquids. 
Ionic liquids (ILs) are organic salts with melting temperature below $100^{\circ} \mathrm{C}$, due to their ions' delocalized charge and asymmetry that prevent crystallization. They are known since 1914, i.e. 100 years, when the first compound $\left[\left(\mathrm{C}_{2} \mathrm{H}_{5}\right) \mathrm{NH}_{3}\right]\left[\mathrm{NO}_{3}\right]$ was synthesized by Paul Walden with melting point $12^{\circ} \mathrm{C}$. ILs are a class of diluents with unusual solvating properties as compared to molecular diluents. ILs differ from the traditional eutectic molten salts $(\mathrm{LiCl} / \mathrm{KCl})$ because most of them are liquid at room temperature. The use of ILs as "environmentally friendly alternative diluents" is in accordance with some of the twelve principles of the green chemistry. ${ }^{[3]}$ The main reason to this can be found in the negligible flammability and volatility that most ILs display (due to their ionic character) in contrast to traditional molecular organic diluents. Thus, the risk of air pollution is minimal due to their non-volatile characteristics. These properties render them inherently safer. Furthermore, ILs are often said to be chemically and thermally stable even up to $350^{\circ} \mathrm{C}$. This implies that they are safe to work with in laboratory and they are very attractive for industrial use, too. As a consequence, in the beginning of $21^{\text {st }}$ century, ILs are one of the most interesting and rapidly developing areas of modern physical chemistry, technologies and engineering ${ }^{[4-8]}$ in view of the reduction of VOCs consumption and waste production.

In particular, in the field of metal extraction/separation/recycling by liquid/liquid processes, hydrophobic ILs of the type $\left[\mathrm{C}_{\mathrm{n}} \mathrm{C}_{\mathrm{m}} \mathrm{im}\right]\left[\mathrm{Tf}_{2} \mathrm{~N}\right]$ (1-alkyl, 3-alkyl-imidazolium bis(trifluoromethylsulfonyl)imide) have already proved to be tremendously efficient media for a large variety of metals, ${ }^{[9]}$ from $\mathrm{Li}^{+}$to $\mathrm{Pu}^{4+},[10,11]$ including d-elements ${ }^{[1,2,11-13]}$ and lanthanoids. ${ }^{[14-19]}$ The huge potential that ILs present for extraction processes is due to complex extraction mechanisms, strongly dependent not only on the nature of the IL but also on the aqueous phase composition, ${ }^{[20]}$ most often based on nitric or hydrochloric acids. Based on several experimental evidences, it is now acknowledged that metal extraction in aqueous-IL systems proceeds mainly by ion exchange, either cationic or anionic, although neutral metal species were also established. ${ }^{[14,21-23]}$

This escape of ILs' components is a serious eco problem (not speaking of the cost drawbacks) and should be controlled limited to a minimum and avoided if possible because all ILs cannot be considered environmentally benign. ${ }^{[24]}$ The "green" character of $\left[\mathrm{C}_{n} \mathrm{C}_{\mathrm{m}} \mathrm{im}\right]\left[\mathrm{Tf}{ }_{2} \mathrm{~N}\right]$ is critically assessed according to EU Hazard codes (T,N) and nowadays, a wealth of experimental works have demonstrated that these ILs and many others are toxic to aquatic and human life. ${ }^{[25-27]}$ It is wrong to assume that the risk hazards of the used precursors (labeled with symbols corrosive, harmful and toxic) will fade away after their conversion into ILs. ${ }^{\text {[25] }}$ So, the possible release into the aquatic environment of either cationic or anionic IL components cannot be neglected because of their potential toxicity and limited biodegradability. ${ }^{[28,29]}$ Many current studies in risk assessment of ILs cover aquatic ecotoxicity, dealing with photoplankton organisms ${ }^{[30,31]}$ or fish. ${ }^{[32]}$ The acute toxicity of 15 widely used ILs to fish (zebrafish, Danio rerio) was evaluated by Pretti et al. ${ }^{[32]}$ The authors have assessed that imidazolium, pyridinium and pyrrolidinium based IL can be regarded as non-highly lethal towards zebrafish $\left(\mathrm{LC}_{50}>100 \mathrm{mgL}^{-1}\right)$. Despite this rather reassuring result, enlarging the knowledge about ILs' hazard potentials to fully understand the prospective fate of ILs to man requests state-of-the art studies of broad concern. This includes works on enzymes, mammalian cells, ${ }^{[33]}$ leukemia, glioma and rat cells ${ }^{[34]}$ as well as investigations of the mutagenicity of ILs. ${ }^{[35]}$ Most tests have indicated that IL toxicity increases with increasing the alkyl chain substituent length. ${ }^{[34]}$ The anion can also contribute to toxicity, but in most cases anion effects are less drastic compared to the side chain effect ${ }^{17}$ and the role of anion type remains uncertain. ${ }^{[25]}$

As a consequence, although ILs have been widely accepted as "greener" diluents, all processes, and in particular, liquid/liquid extraction of metals, in which the gradual dissolution of cationic and anionic constituents of IL into the aqueous phase occurs must be 
characterized and controlled. Obviously, ionic exchange is unavoidable in aqueous/IL biphasic systems because owing to the polarity of water and the presence of ions as IL components, there will always be interactions between ions from the two phases, as mixing offers a better energy balance. ${ }^{[20]}$ Some authors have thus questioned the greenness of ILs. ${ }^{[36]}$

Clearly, the knowledge of the mutual solubilities of water and ILs is important as regards their applications as liquid media in the chemical engineering field. To understand and master the behavior of IL-based extraction systems it is helpful to begin by considering analogous systems in the absence of a metal ion as well as an extractant. Such studies are of interest to the field of metallic extraction but also on a wider perspective, in order to predict their eco impact and to overcome their leaching drawback by adjusting their chemical composition. ${ }^{\text {[29] }}$ The purpose of the present work is thus to study the influence of three strong monobasic acids often used in liquid/liquid extraction of metallic ions ${ }^{[37]}\left(\mathrm{HClO}_{4}, \mathrm{p} K_{\mathrm{a}}=-10 ; \mathrm{HCl}, \mathrm{p} K_{\mathrm{a}} \approx-3\right.$; $\left.\mathrm{HNO}_{3}, \mathrm{p} K_{\mathrm{a}}<-1\right)$ and of their corresponding sodium salts onto the loss of IL components to aqueous phases. For this reason, the efforts to examine chloride, nitrate and perchlorate-based aqueous phases in contact with ILs $\left(\left[\mathrm{C}_{1} \mathrm{C}_{\mathrm{n}} \mathrm{im}\right]\left[\mathrm{Tf}_{2} \mathrm{~N}\right], \mathrm{n}=2,4,6,8\right.$ and 10) began with the determination of the concentrations of various entities $\left(\mathrm{D}^{+}, \mathrm{D}_{2} \mathrm{O}\right.$-as NMR surrogates of $\mathrm{H}^{+}$ and $\mathrm{H}_{2} \mathrm{O}-, \mathrm{Tf}_{2} \mathrm{~N}^{-}, \mathrm{C}_{1} \mathrm{C}_{\mathrm{n}} \mathrm{im}^{+}$) in the lower and upper phases. Other experiments were focused on the effect of ionic strength $\left(0.1 \mathrm{M}\right.$ for $\mathrm{NaCl}$ and $\mathrm{NaNO}_{3}$, and $0.1 \mathrm{M}, 0.2 \mathrm{M}, 0.4 \mathrm{M}$ for $\mathrm{NaClO}_{4}$ ) on the solubilities. The obtained results give some insights into the fundamental aspects of the behavior of ILs, as a practical value in efforts to employing these unique diluents as innovative organic phases for metal ion extraction and separation and other applications.

\section{Experimental Section}

Reagents: The ILs 1-ethyl-, 1-butyl-, 1-hexyl-, 1-octyl- and 1-decyl-3-methyl-imidazoliumbis(trifluoromethanesulfonyl)imide, (purity, 99.5\%) were purchased from Solvionic (Toulouse, France). ILs unavoidably absorb $\mathrm{H}_{2} \mathrm{O}$ from the atmosphere and their average water content is ca. $200 \mathrm{ppm}$ as purchased. Thus, ILs were dried under vacuum following a previously published procedure ${ }^{[38]}$ prior to sample preparation. Due to their hydrophobicity, they can be dried to very low final water contents $(20 \mathrm{ppm})$ prior to mixing. All aqueous solutions have been prepared with deuterated water $(99.9$ atom $\% \mathrm{D}$, Aldrich). The mineral acids are $\mathrm{DCl}(35 \%), \mathrm{DNO}_{3}(65 \%)$ and $\mathrm{DClO}_{4}(68 \%)$ (in $\mathrm{D}_{2} \mathrm{O}, 99$ atom $\% \mathrm{D}$, Aldrich). The internal standard used in ${ }^{1} \mathrm{H}$ NMR is trisodium citrate dehydrate (Sigma-Aldrich, 99\%) chosen because its protons are well separated from those of the studied IL's cations. The standard used in ${ }^{19} \mathrm{~F}$ NMR is sodium trifluoroacetate (Alfa Aesar, 98\%). 1-methyl-3-octylimidazolium chloride is with purity $>97 \%$ (Aldrich) for T1 measurements. All deuterated solutions were stored under nitrogen in order to avoid hydrogen exchange with the atmosphere. ${ }^{[39]}$ All other reagents purchased from Merck used in this study were of analytical grade and were used without any further purification.

Apparatus: Mechanical shaker model IKA Vibrax VXR was used as well as centrifuge Micro Star 12 for contacting/separating phases. The $\mathrm{D}_{2} \mathrm{O}$ amount in the IL phases was titrated by the Karl Fischer method with a coulometer (Mettler Toledo DL 32). The uncertainty is equal to $5 \%$. Owing to the redox reaction at the basis of the Karl-Fischer titration, the water content of samples containing $\mathrm{ClO}_{4}{ }^{-}$anions cannot be reliably measured and is thus not presented. As a precaution, Karl-Fischer data for samples containing nitrate ions are also not displayed. The $\mathrm{pD}$ values of the deuterated aqueous solutions (before and after contact with the IL phases, $\mathrm{n}$ $=4,6,8,10$ ) were measured by Schott titrator (Titroline Easy). The uncertainty is equal to $0.5 \%$. For these two methods no particular caution was set concerning the use of $\mathrm{D}_{2} \mathrm{O} / \mathrm{D}^{+}$ instead of $\mathrm{H}_{2} \mathrm{O} / \mathrm{H}^{+}$. All NMR spectra were recorded on a Bruker Avance $300 \mathrm{MHz}$ (Probe head: P BBO 300S1 BBF-H-D-05Z). 
Aqueous-ionic liquid biphasic systems: In this paper, the term "aqueous" refers only to $\mathrm{D}_{2} \mathrm{O}$ and "aqueous phase composition" refers to composition prior to equilibration with the IL phase. All systems studied are biphasic under ambient temperature conditions once aqueous and IL phases are contacted and neither third phase formation nor phase inversion could be observed for any of the systems. Therefore, in order to designate the two phases, we will refer to the lower and upper phase, the latter being a $\mathrm{D}_{2} \mathrm{O}$-rich phase (in mole fraction). Subscripts " $u$ " and " $\ell$ " will designate such phases. Equal volumes $(0.8 \mathrm{ml})$ of aqueous phase (containing or not $0.1 \mathrm{M} \mathrm{NaCl}$ or $\mathrm{NaNO}_{3}, 0.1,0.2$ or $0.4 \mathrm{M}$ of $\mathrm{NaClO}_{4}$ and adjusted to the initial desired $\mathrm{pD}_{\text {in }}$ with $\mathrm{DCl}, \mathrm{DNO}_{3}$ and $\mathrm{DClO}_{4}$ accordingly) and organic phase (different ILs) were equilibrated for 2 hours $(1500 \mathrm{rpm})$ at $(22 \pm 2){ }^{\circ} \mathrm{C}$ by mechanical shaking. After centrifugation ( 2 minutes, $5000 \mathrm{rpm}$ ) and phase separation the $\mathrm{pD}$ of the upper phase was measured and taken as equilibrium value, $\mathrm{pD}_{\text {eq }}$. Conversely, the $\mathrm{D}_{2} \mathrm{O}$ amount was measured in the lower phase.

Protocol for NMR measurements: An experimental protocol using quantitative NMR for the determination of IL's cations and anions solubilized in the upper phases was recently developed by Mazan et al. ${ }^{[20]}$ and was applied in the present study. Detection limits for $\left[\mathrm{Tf}_{2} \mathrm{~N}^{-}\right]$and $\left[\mathrm{C}_{1} \mathrm{C}_{\mathrm{n}} \mathrm{im}^{+}\right]$are in the range of 1- $2 \mathrm{mM}$. Experimental uncertainties are equal to $10 \%$ for $\left[\mathrm{C}_{1} \mathrm{C}_{\mathrm{n}} \mathrm{im}^{+}\right]$and to $5 \%$ for $\left[\mathrm{Tf}_{2} \mathrm{~N}^{-}\right]$.

\section{Results and Discussion}

\section{1. $D^{+}$extraction to the $\left[\mathrm{C}_{1} \mathrm{C}_{\mathbf{n}} \mathrm{im}\right]\left[\mathrm{Tf}_{2} \mathrm{~N}\right]$ ILs}

The solubility of $\left[\mathrm{D}^{+}\right]$, in the presence or absence of the corresponding salt, in $\left[\mathrm{C}_{1} \mathrm{C}_{\mathrm{n}} \mathrm{im}\right]\left[\mathrm{Tf}_{2} \mathrm{~N}\right]$ was determined as a function of $\mathrm{pD}_{\mathrm{in}}$. The results are presented in Figure 1 for $\left[\mathrm{C}_{1} \mathrm{C}_{10} \mathrm{im}\right]\left[\mathrm{Tf}_{2} \mathrm{~N}\right]$, in Fig. 2 for $\left[\mathrm{C}_{1} \mathrm{C}_{4} \mathrm{im}\right]\left[\mathrm{Tf}_{2} \mathrm{~N}\right]$ and in Figures $\mathrm{S} 1-\mathrm{S} 2$ for $\mathrm{n}=8$ and 6.

Using $\left[\mathrm{C}_{1} \mathrm{C}_{10} \mathrm{im}\right]\left[\mathrm{Tf}_{2} \mathrm{~N}\right]$ and $\left[\mathrm{C}_{1} \mathrm{C}_{8} \mathrm{im}\right]\left[\mathrm{Tf}_{2} \mathrm{~N}\right]$ no deviation from the $\mathrm{y}=\mathrm{x}$ line (i.e. $\mathrm{pD}$ in $=\mathrm{pD}_{\mathrm{eq}}$, dotted line in the figures) can be observed up to $\mathrm{pD}_{\text {in }}=6$, although a slight deviation could be seen for $\mathrm{n}=10$ above $\mathrm{pD}_{\text {init }}=6$ and no effect of composition of the aqueous phase is seen. $\mathrm{By}$ comparison to a limited data set recently obtained by us for non-deuterated systems and in the absence of perchlorate salts, ${ }^{[40]}$ no significant isotopic effect could be detected between $\mathrm{pH}_{\mathrm{eq}}$ and $\mathrm{pD}$ eq variations for $\left[\mathrm{C}_{1} \mathrm{C}_{10} \mathrm{im}\right]\left[\mathrm{Tf}_{2} \mathrm{~N}\right]$ and $\left[\mathrm{C}_{1} \mathrm{C}_{8} \mathrm{im}\right]\left[\mathrm{Tf}_{2} \mathrm{~N}\right]$ up to $\mathrm{pH}_{\text {in }} / \mathrm{pD}$ in $=8$. The results illustrated in Figs. 1 and S2 show that no significant solubilisation of $\mathrm{D}^{+}$in the lower phase occurs in such biphasic systems.

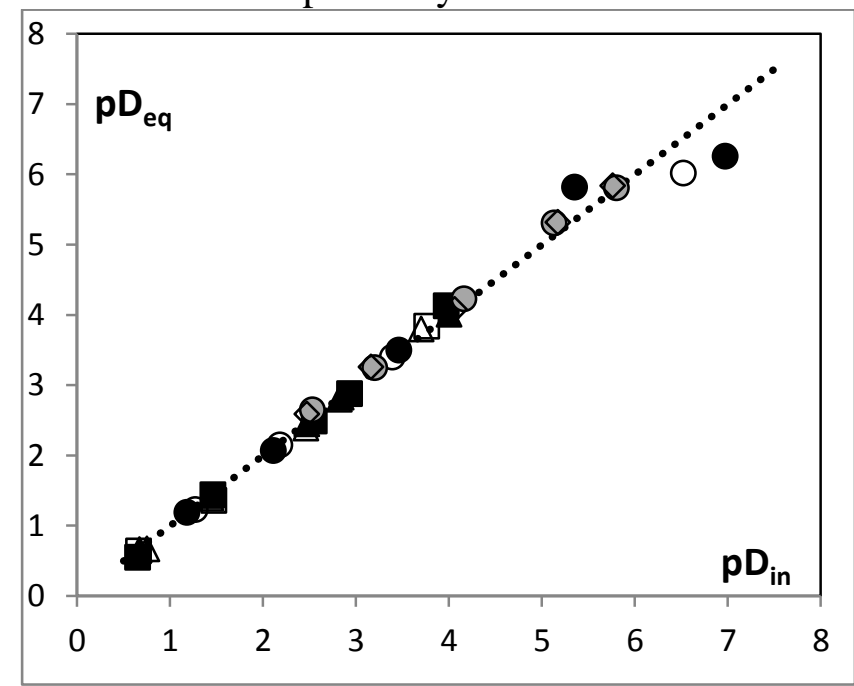

Figure 1. $\mathrm{pD}$ eq $v s . \mathrm{pD}_{\text {in }}$ of the aqueous phases using $\left[\mathrm{C}_{1} \mathrm{C}_{10} \mathrm{im}\right]\left[\mathrm{Tf}_{2} \mathrm{~N}\right]$ as organic medium. Dotted line: $\mathrm{y}=\mathrm{x} . \square: \mathrm{DNO}_{3}$. $\mathbf{\mathrm { DNO } _ { 3 }}$ and $\mathrm{NaNO}_{3} 0.1 \mathrm{M} . \Delta: \mathrm{DCl} ; \boldsymbol{\Delta}: \mathrm{DCl}$ and $\mathrm{NaCl} 0.1 \mathrm{M}$; ○: $\mathrm{DClO}_{4} ; \bullet: \mathrm{DClO}_{4}$ and $\mathrm{NaClO}_{4} 0.1 \mathrm{M}$; ○: $\mathrm{DClO}_{4}$ and $\mathrm{NaClO}_{4} 0.2 \mathrm{M}$; $: \mathrm{DClO}_{4}$ and $\mathrm{NaClO}_{4}$ $0.4 \mathrm{M}$. 
By contrast, when $\left[\mathrm{C}_{1} \mathrm{C}_{4} \mathrm{im}\right]\left[\mathrm{Tf}_{2} \mathrm{~N}\right]$ and $\left[\mathrm{C}_{1} \mathrm{C}_{6} \mathrm{im}\right]\left[\mathrm{Tf}_{2} \mathrm{~N}\right]$ (Figures 2 and $\mathrm{S} 1$, respectively) are used, a clear deviation from the line $\mathrm{y}=\mathrm{x}$ is observed, as the result of the solubility of $\mathrm{D}^{+}$in the lower phase, that leads to increase of the equilibrium $\mathrm{pD}$ values in the upper phase. In $\left[\mathrm{C}_{1} \mathrm{C}_{6} \mathrm{im}\right]\left[\mathrm{Tf}_{2} \mathrm{~N}\right]$, deviation from the $\mathrm{y}=\mathrm{x}$ line is observed above $\mathrm{pD}_{\text {in }}=2$ and the effect of aqueous phase composition is hardly seen. The plateau value is equal to ca. 8 .

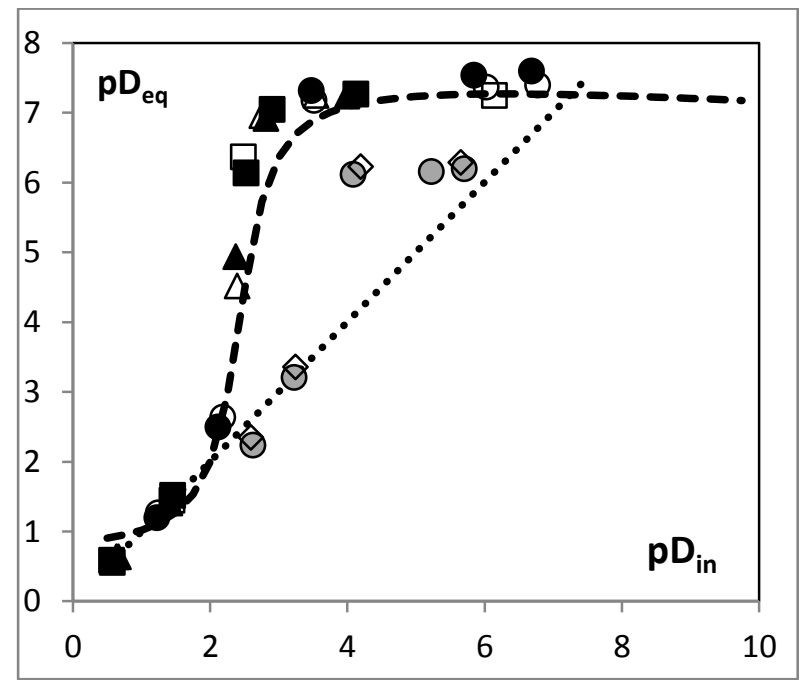

Figure 2. $\mathrm{pD}_{\text {eq }} v$ s. $\mathrm{pD}_{\text {in }}$ of the aqueous phases using $\left[\mathrm{C}_{1} \mathrm{C}_{4} \mathrm{im}\right]\left[\mathrm{Tf}_{2} \mathrm{~N}\right]$ as organic medium. Dotted line: $\mathrm{y}=\mathrm{x}$. Dashed line: empirical function used for non-deuterated non-perchlorated samples (see text). Symbols as in Fig. 1.

For $\left[\mathrm{C}_{1} \mathrm{C}_{4} \mathrm{im}\right]\left[\mathrm{Tf}_{2} \mathrm{~N}\right]$, no experimental differences can be observed between samples containing $\mathrm{DCl}, \mathrm{DNO}_{3}$ and $\mathrm{DClO}_{4}$ with or without their corresponding salt at $0.1 \mathrm{M}$. By contrast, samples with sodium perchlorate concentrations equal to $0.2 \mathrm{M}$ and $0.4 \mathrm{M}$ deviate from the $\mathrm{y}=\mathrm{x}$ line above $\mathrm{pD}_{\text {in }}=3.2$, with a plateau at $\mathrm{pD}_{\text {eq }}=6.2$, while all other sample compositions lead to a deviation already above $\mathrm{pD}_{\text {in }}=2$ and a plateau value at $\mathrm{pD}$ eq $\approx 7.4$. For $\mathrm{DCl}$ samples having initial $\mathrm{pD}$ values at 2.75 and 3.54 , the measured $\mathrm{pD}$ values after contact with $\left[\mathrm{C}_{1} \mathrm{C}_{4} \mathrm{im}\right]\left[\mathrm{Tf}_{2} \mathrm{~N}\right]$ were 6.96 and 7.25 , respectively.

Sigmoid curves of this kind were also obtained in our previous work dealing with nondeuterated and non-perchlorated samples ${ }^{[40]}$ and were fitted by a purely empirical expression. Such calculated variations are shown in Fig. 2 as a dashed line. The very good agreement between the calculated and experimental variation shows that isotopic effect is very limited. Fig. 2 also illustrates a significant difference between samples containing large (i.e. > $0.1 \mathrm{M}$ ) amounts of sodium perchlorate and all other aqueous phase compositions.

To the best of our knowledge, such $\mathrm{pD}_{\mathrm{eq}} v s \mathrm{pD}_{\text {in }}$ results are unprecedented in the literature, as only very limited data have been published in this $\mathrm{pH} / \mathrm{pD}$ range. For example, it has been found by titration that $79 \%$ of the total amount of the nitric acid $(\mathrm{pH}=2)$ is transferred to $\left[\left(\mathrm{CH}_{3}\right)_{3} \mathrm{~N}\left(\mathrm{CH}_{2} \mathrm{CH}_{2} \mathrm{OMe}\right)\right]\left[\mathrm{Tf}_{2} \mathrm{~N}\right]$, but this was obtained in the presence of ca. $10^{-2} \mathrm{M}$ of uranyl nitrate, a situation very different from ours. ${ }^{[41]}$ Although the authors do not comment on this aspect, we hypothesize that this is due, apart from the difference in ILs used which certainly has an impact onto nitric acid solubility, to the rather large uranium amount (more or less equal to the $\mathrm{H}^{+}$amount) which would allow for some $\mathrm{U}(\mathrm{VI})$ hydrolysis and/or precipitation.

\subsection{Water dragging to the IL phase}

Figure 3 displays the $\mathrm{D}_{2} \mathrm{O}$ amount in the lower phase as a function of $\mathrm{pD}_{\mathrm{eq}}$ values and sample composition (chloride data only, see experimental section) for $\left[\mathrm{C}_{1} \mathrm{C}_{4} \mathrm{im}\right]\left[\mathrm{Tf}{ }_{2} \mathrm{~N}\right]$ equilibration, as an illustration of our results. Data for the other IL phases can be found in the supplementary materials (Fig. S3) No significant effect of $\mathrm{D}^{+} / \mathrm{Na}^{+}$composition of the aqueous 
phase onto $\mathrm{D}_{2} \mathrm{O}$ transfer to the IL was observed in the $\mathrm{pD}$ range investigated for a given IL but the decrease in water solubilisation is clearly seen as a function of $\mathrm{n}$ (approximately more than $-60 \%$ in $\mathrm{D}_{2} \mathrm{O}$ solubility changing $\mathrm{C}_{1} \mathrm{C}_{2} \mathrm{im}^{+}$with $\mathrm{C}_{1} \mathrm{C}_{10} \mathrm{im}^{+}$, Fig. 4). This is ascribable to the increase in hydrophobicity of the IL phase by changing the cation, keeping the same anion:

$\mathrm{C}_{1} \mathrm{C}_{2} \mathrm{im}^{+}>\mathrm{C}_{1} \mathrm{C}_{4} \mathrm{im}^{+}>\mathrm{C}_{1} \mathrm{C}_{6} \mathrm{im}^{+}>\mathrm{C}_{1} \mathrm{C}_{8} \mathrm{im}^{+}>\mathrm{C}_{1} \mathrm{C}_{10} \mathrm{im}^{+}$

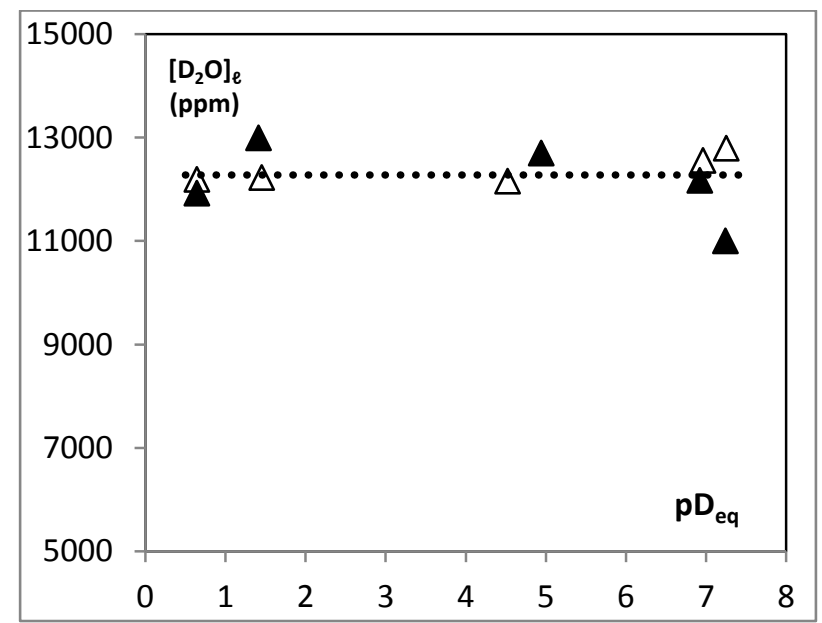

Figure 3. $\mathrm{D}_{2} \mathrm{O}$ amount in the lower phase $v s$. $\mathrm{pD}_{\text {eq }}$ of the aqueous phase using $\left[\mathrm{C}_{1} \mathrm{C}_{4} \mathrm{im}\right]\left[\mathrm{Tf}_{2} \mathrm{~N}\right]$ as organic medium. $\Delta$ : $\mathrm{DCl} ; \boldsymbol{\Delta}: \mathrm{DCl}$ and $\mathrm{NaCl} 0.1 \mathrm{M}$. Dotted line: average value of all data.

The obtained average values are in very good agreement with our recent investigation using non deteurated water. ${ }^{[40]}$ Our present data fit well also with the data published by the group of Coutinho $^{[29]}$ when ultra-pure water was used at $25^{\circ} \mathrm{C}:\left[\mathrm{C}_{1} \mathrm{C}_{6} \mathrm{im}^{+}\right]$: $10540 \mathrm{ppm} ;\left[\mathrm{C}_{1} \mathrm{C}_{8} \mathrm{im}^{+}\right]$: $8700 \mathrm{ppm}$, while they differ slightly for $\left[\mathrm{C}_{1} \mathrm{C}_{4} \mathrm{im}^{+}\right]: 14600 \mathrm{ppm}$. This may be due to the longer mixing time of $48 \mathrm{~h}$ used by the Portuguese group, assuring the complete saturation of this rather hydrophilic IL phase. ${ }^{[29]}$

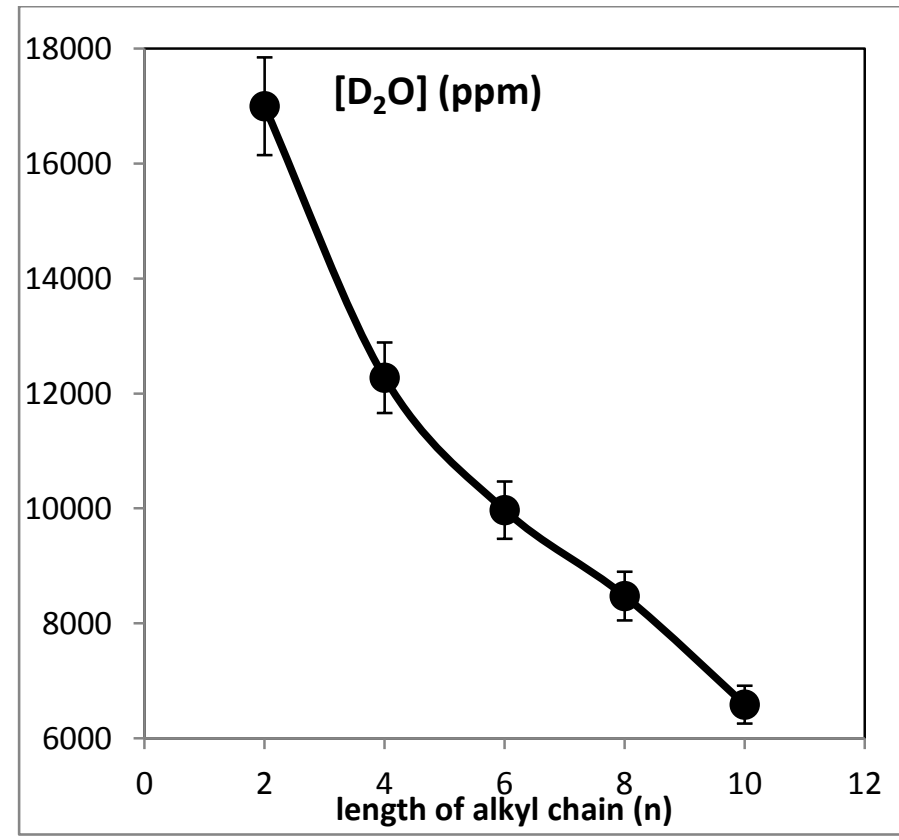

Figure 4. $\mathrm{D}_{2} \mathrm{O}$ average amount (ppm) in the lower phase $v s$. $\mathrm{n}$ (the length of the IL cation $\mathrm{C}_{1} \mathrm{C}_{\mathrm{n}} \mathrm{im}^{+}$). Solid line is a guide for the eye only. 


\subsection{Concentration of IL's anions and cations in the upper phase}

Conversely, the quantities $(\mathrm{mM})$ of the IL's entities transferred from the lower to the upper phase were measured by inspection of the ${ }^{1} \mathrm{H}$ and ${ }^{19} \mathrm{~F}$ NMR spectra, (NMR raw data in Figures S8-S15) and plotted against the values of $\mathrm{pD}$ at equilibrium. It is important to recall that ion distributions between the two phases can lead to non-identical amounts of $\left[\mathrm{C}_{1} \mathrm{C}_{\mathrm{n}} \mathrm{im}^{+}\right]$ and $\left[\mathrm{Tf}_{2} \mathrm{~N}^{-}\right]$in the upper phase, because charge balance can be achieved by joint solubilisation or transfer of $\mathrm{D}^{+}, \mathrm{Na}^{+}$and/or $\mathrm{NO}_{3}^{-}, \mathrm{Cl}^{-}$or $\mathrm{ClO}_{4}^{-}$, accordingly.

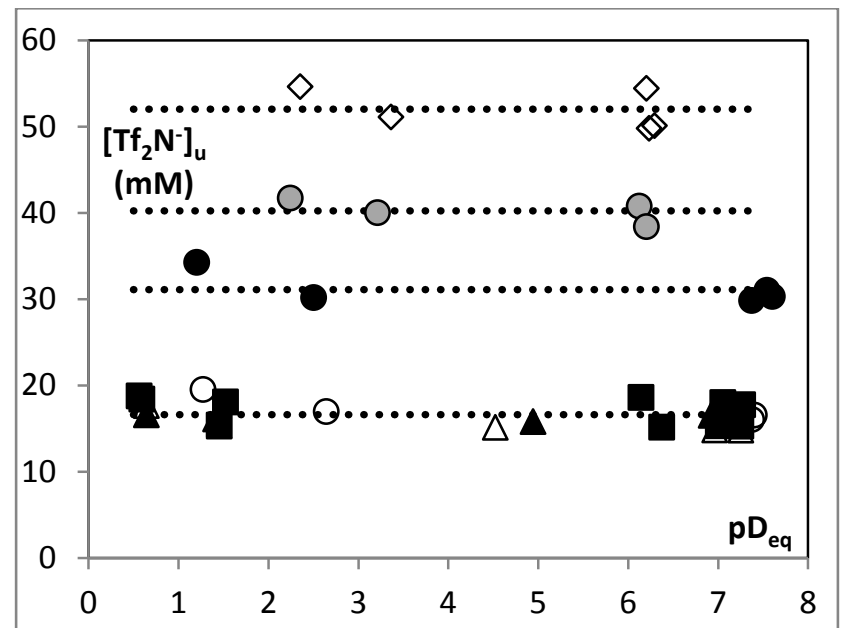

Figure 5. $\left[\mathrm{Tf}_{2} \mathrm{~N}^{-}\right]_{\mathrm{u}}$ vs. $\mathrm{pD}$ eq in the aqueous phases using $\left[\mathrm{C}_{1} \mathrm{C}_{4} \mathrm{im}\right]\left[\mathrm{Tf}_{2} \mathrm{~N}\right]$ as organic medium. Symbols as in Fig. 1. Dotted lines are average of individual series (see text).

For one given $\mathrm{IL}, \mathrm{Tf}_{2} \mathrm{~N}^{-}$solubility in the upper phase is strongly dependent on the aqueous phase composition, but does not vary significantly as a function of $\mathrm{pD}_{\mathrm{eq}}$ as illustrated in Fig. 5 for $\left[\mathrm{C}_{1} \mathrm{C}_{4} \mathrm{im}\right]\left[\mathrm{Tf}_{2} \mathrm{~N}\right](\mathrm{S} 4-\mathrm{S} 7: \mathrm{n}=2,6,8,10$, respectively). Consequently, all values discussed below are averaged on all $\mathrm{pD}_{\mathrm{eq}}$ values. Using $\left[\mathrm{C}_{1} \mathrm{C}_{4} \mathrm{im}\right]\left[\mathrm{Tf}_{2} \mathrm{~N}\right]$, samples without sodium perchlorate display similar ionic solubilities at ca. $17 \mathrm{mM}$, a value in agreement with our previously published data for the same IL phase: $c a$. $15 \mathrm{mM}$ in pure $\mathrm{H}_{2} \mathrm{O}{ }^{[20]}$ Our value (corresponding to $0.7 \mathrm{wt} \%$ of $\mathrm{C}_{1} \mathrm{C}_{4} \mathrm{im}^{+}$in $\mathrm{H}_{2} \mathrm{O}$ ) is also in fair agreement with the $\mathrm{C}_{1} \mathrm{C}_{4} \mathrm{im}^{+}$data of Freire and co-workers, ${ }^{[42]}$ equal to $20 \mathrm{mM}$ (average of values at $0.1 \mathrm{M}, 0.2 \mathrm{M}$ and $0.5 \mathrm{M}$ of added $\mathrm{NaCl}$ salt, no $\mathrm{pH}$ control) or $19 \mathrm{mM}$ (average of values at $0.1 \mathrm{M}, 0.2 \mathrm{M}$ and $0.5 \mathrm{M}$ of added $\mathrm{NaNO}_{3}$ salt, no $\mathrm{pH}$ control). Addition of sodium perchlorate induces a large increase in $\mathrm{Tf}_{2} \mathrm{~N}^{-}$solubility, which rises to $31 \mathrm{mM}, 40 \mathrm{mM}$ and $52 \mathrm{mM}$ for $0.1 \mathrm{M}, 0.2 \mathrm{M}$ and $0.4 \mathrm{M}$ of $\mathrm{NaClO}_{4}$ added, respectively. Assuming no change in equilibrium volume of the aqueous phase, this corresponds to ca $1.5 \%$ of the total $\mathrm{Tf}_{2} \mathrm{~N}^{-}$amount which is lost to the aqueous phase at maximum. This effect of sodium perchlorate addition is also observed for $\mathrm{n}=2, \mathrm{n}=$ 6 and $\mathrm{n}=8$, but it stabilizes at $\approx 20 \mathrm{mM}$ for $\mathrm{n}=10$. On another hand, for a given aqueous phase composition, $\mathrm{Tf}_{2} \mathrm{~N}^{-}$solubility in the upper phase decreases as $\mathrm{n}$ increases. Note that already with $\mathrm{n}=6, \mathrm{Tf}_{2} \mathrm{~N}^{-}$solubility values for the samples without sodium perchlorate are very close to the detection limit, with an average value at ca. $5 \mathrm{mM}$ and are below the detection limit for $n=8$ and 10. Similarly, samples with sodium perchlorate display $\mathrm{Tf}_{2} \mathrm{~N}^{-}$ solubilities in the upper phase below the detection limit for $n=8$ and 10 . These values are thus not displayed in the corresponding figures.

For a better understanding of this phenomenon, this double tendency is illustrated in Fig. 6 (data plotted as a function of added sodium perchlorate) and Fig. 7 (data plotted as a function of $\mathrm{n})$. All data are collected in Table 1. 


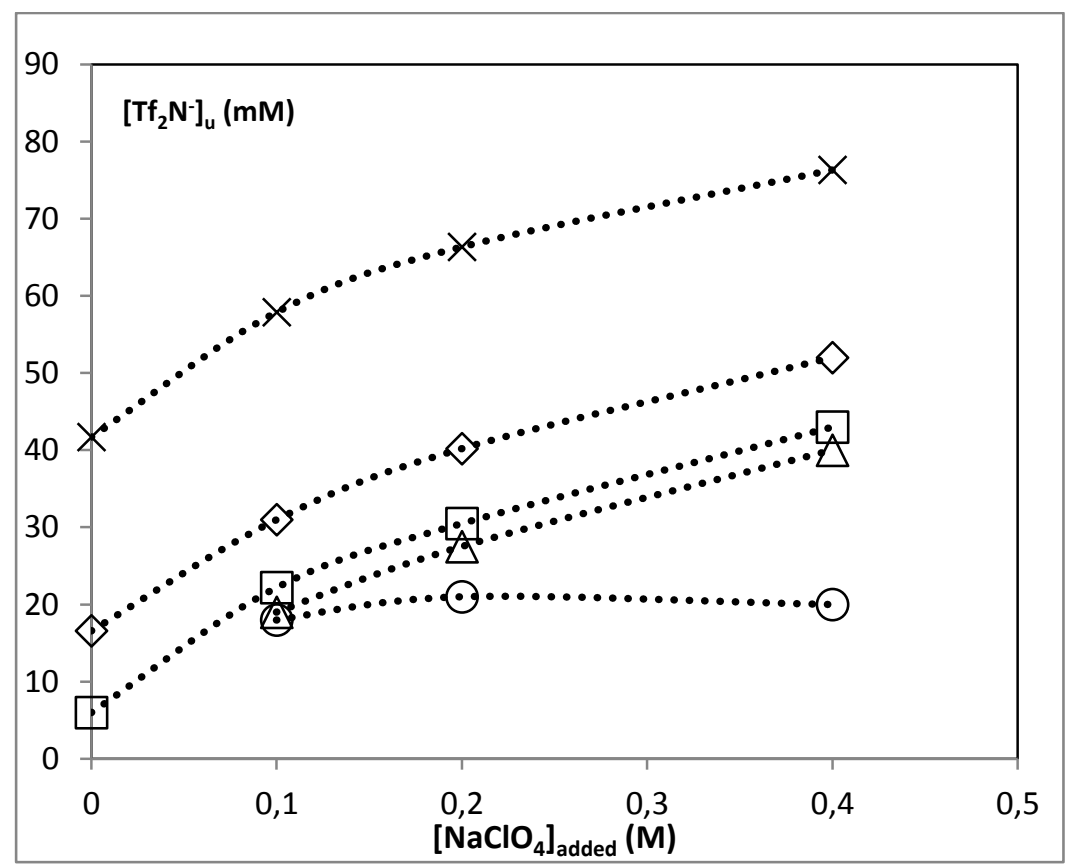

Figure 6. Average values of $\mathrm{Tf}_{2} \mathrm{~N}^{-}$solubility in the upper phase, as a function of added sodium perchlorate concentration for the four ILs of this work. $x: n=2 ; \diamond: n=4 ; \square: n=6 ; \Delta$ : $\mathrm{n}=8 ; \circ: \mathrm{n}=10$. Dotted lines are guide for the eye only.

None of the ILs cation solubilities in the upper phase could be recorded for $n=10$ and 8 as all data are below the detection limit and are very close to it for $n=6$. Consequently, trends are difficult to derive. For the lower alkyl chain lengths $(n=6,4,2)$, and in the absence of sodium perchlorate, IL cation solubilities are similar for all $\mathrm{pD}_{\mathrm{eq}}$ values, although data for $\mathrm{DClO}_{4}$ are somewhat more dispersed, and present a decreasing trend as $\mathrm{n}$ increases, in accord with the hydrophobicity of the cation: $\left[\mathrm{C}_{1} \mathrm{C}_{2} \mathrm{im}^{+}\right]_{\mathrm{u}}=40 \mathrm{mM},\left[\mathrm{C}_{1} \mathrm{C}_{4} \mathrm{im}^{+}\right]_{\mathrm{u}}=17 \mathrm{mM}$ and $\left[\mathrm{C}_{1} \mathrm{C}_{6} \mathrm{im}^{+}\right]_{\mathrm{u}}=6$ $\mathrm{mM}$ (average values for all $\mathrm{pD}_{\mathrm{eq}}$ ). Addition of sodium perchlorate seems to induce a limited decrease in $\mathrm{C}_{1} \mathrm{C}_{\mathrm{n}} \mathrm{im}^{+}$amount, of ca. $4-6 \mathrm{mM}(\mathrm{n}=2$ and 4$)$. For $\mathrm{n}=6$, the values in presence of sodium perchlorate are very close to the detection limit (see Figs. 8, $\mathrm{n}=6$ ).

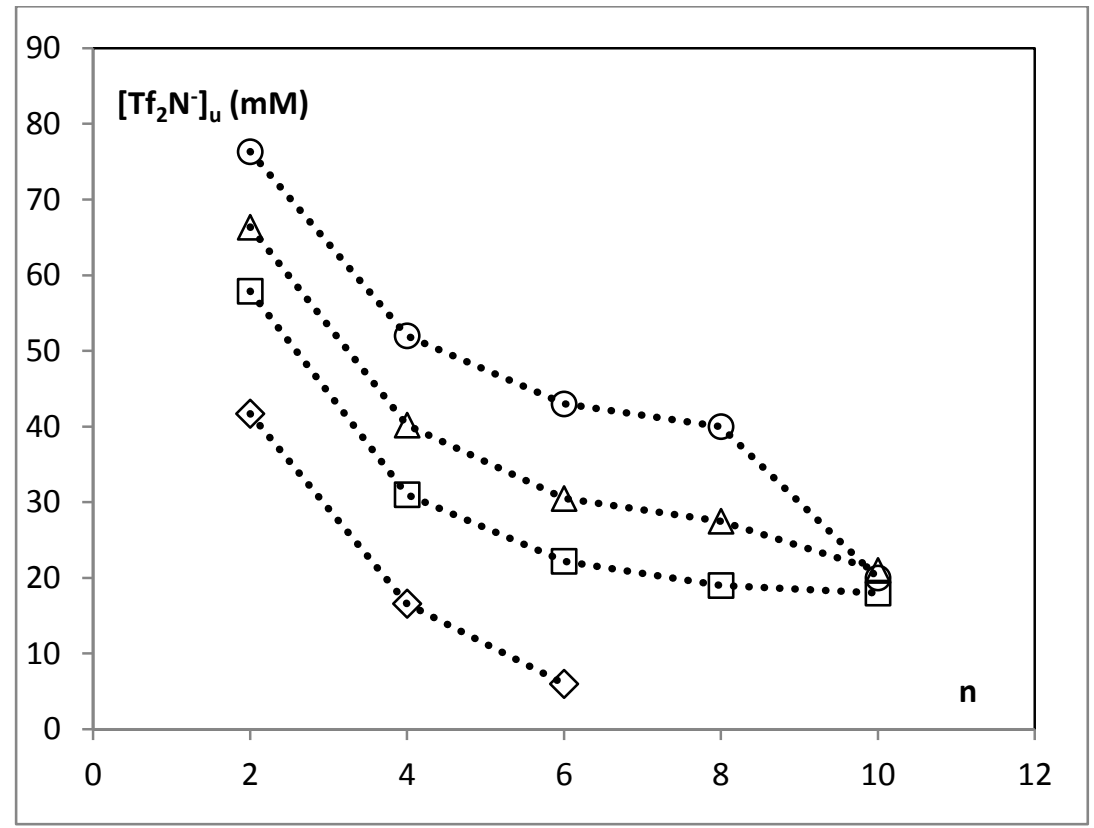


Figure 7: Average values of $\mathrm{Tf}_{2} \mathrm{~N}^{-}$solubility in the upper phase, as a function of length of the alkyl chain, for the various sodium perchlorate concentrations of this work. $\diamond$ : no sodium perchlorate; $\square:\left[\mathrm{NaClO}_{4}\right]_{\text {added }}=0.1 \mathrm{M} ; \Delta:\left[\mathrm{NaClO}_{4}\right]_{\text {added }}=0.2 \mathrm{M} ; \circ:\left[\mathrm{NaClO}_{4}\right]_{\text {added }}=0.4 \mathrm{M}$. Dotted lines are guide for the eye only.

The obtained values are in good agreement with previous published data: $c a .5 \mathrm{mM}$ for $\left[\mathrm{C}_{1} \mathrm{C}_{6} \mathrm{im}^{+}\right]\left[\mathrm{Tf}_{2} \mathrm{~N}^{-}\right]$contacted with pure $\mathrm{H}_{2} \mathrm{O}^{[43]}$ or $16 \mathrm{mM}$ using $\left[\mathrm{C}_{1} \mathrm{C}_{4} \mathrm{im}\right]\left[\mathrm{Tf}_{2} \mathrm{~N}\right]$ in contact with pure $\mathrm{H}_{2} \mathrm{O}$ at $20^{\circ} \mathrm{C}^{[44]}$ or $16.5 \mathrm{mM}$ at $25^{\circ} \mathrm{C}^{[45]}$

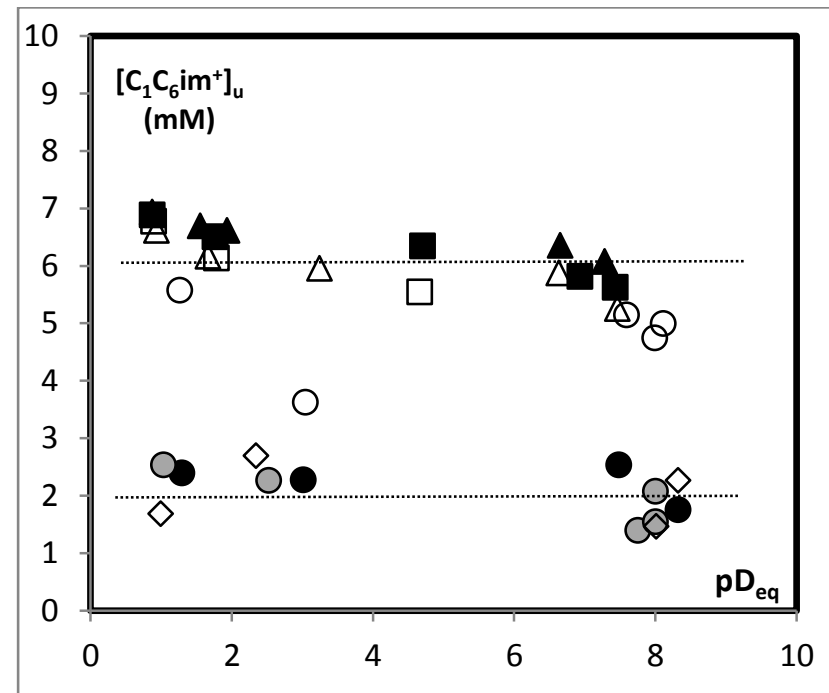

Figure 8. $\left[\mathrm{C}_{1} \mathrm{C}_{6} \mathrm{im}^{+}\right]_{\mathrm{u}}$ vs. $\mathrm{pD}$ eq of the aqueous phases using $\left[\mathrm{C}_{1} \mathrm{C}_{6} \mathrm{im}\right]\left[\mathrm{Tf}_{2} \mathrm{~N}\right]$ as organic medium. Symbols as in Fig. 1. Dashed lines: averages at $6 \mathrm{mM}$ and $2 \mathrm{mM}$. 
Table 1: Values of the equilibrium concentration of $\mathrm{Tf}_{2} \mathrm{~N}^{-}$and $\mathrm{C}_{1} \mathrm{C}_{\mathrm{n}} \mathrm{im}^{+}$in the upper phase.

\begin{tabular}{|c|c|c|c|c|}
\hline & \multicolumn{2}{|c|}{ without $\mathrm{NaClO}_{4}$} & \multicolumn{2}{|c|}{$\begin{array}{c}\text { with } \mathrm{NaClO}_{4} \\
(0.1 \mathrm{M} / 0.2 \mathrm{M} / 0.4 \mathrm{M})\end{array}$} \\
\hline $\mathrm{n}$ & $\begin{array}{l}{\left[\mathrm{Tf}_{2} \mathrm{~N}^{-}\right]_{\mathrm{u}}} \\
(\mathrm{mM})\end{array}$ & $\begin{array}{l}{\left[\mathrm{C}_{1} \mathrm{C}_{\mathrm{n}} \mathrm{im}^{+}\right]_{\mathrm{u}}} \\
(\mathrm{mM})\end{array}$ & $\begin{array}{l}{\left[\mathrm{Tf}_{2} \mathrm{~N}^{-}\right]_{\mathrm{u}}} \\
(\mathrm{mM})\end{array}$ & $\begin{array}{l}{\left[\mathrm{C}_{1} \mathrm{C}_{\mathrm{n}} \mathrm{im}^{+}\right]_{\mathrm{u}}} \\
(\mathrm{mM})\end{array}$ \\
\hline \multirow{3}{*}{2} & \multirow{3}{*}{42} & \multirow{3}{*}{40} & 58 & 38 \\
\hline & & & 66 & 38 \\
\hline & & & 76 & 36 \\
\hline \multirow{3}{*}{4} & \multirow{3}{*}{17} & \multirow{3}{*}{16} & 31 & 21 \\
\hline & & & 40 & 9 \\
\hline & & & 52 & 10 \\
\hline \multirow{3}{*}{6} & \multirow{3}{*}{5} & \multirow{3}{*}{6} & 22 & \multirow{3}{*}{ bdl } \\
\hline & & & 31 & \\
\hline & & & 43 & \\
\hline \multirow{3}{*}{8} & \multirow{3}{*}{ bdl } & \multirow{3}{*}{ bdl } & 19 & \multirow{3}{*}{ bdl } \\
\hline & & & 28 & \\
\hline & & & 40 & \\
\hline \multirow{3}{*}{10} & \multirow{3}{*}{ bdl } & \multirow{3}{*}{ bdl } & 19 & \multirow{3}{*}{ bdl } \\
\hline & & & 21 & \\
\hline & & & 20 & \\
\hline
\end{tabular}

bdl: below detection limit. Values are averages calculated on the basis of all experimental samples (pD 1-8).

\section{Discussion}

In the range of chemical conditions of this work, our data show that the amount of water solubilized in the lower phase neither depends on $\mathrm{pD}_{\mathrm{in}}$, nor on aqueous phase composition. In particular, although $\mathrm{NaCl}$ has some well-acknowledged salting-out effect, addition up to $0.1 \mathrm{M}$ has no significant impact onto water dragging, while changes in water solubility is observed for higher concentrations. ${ }^{[42]}$ More precisely, Previous experimental results by Freire and co-workers on water solubilities in $\left[\mathrm{C}_{1} \mathrm{C}_{4} \mathrm{im}\right]\left[\mathrm{Tf}_{2} \mathrm{~N}\right]$ upon various chemical conditions (several salts, several concentrations, $\mathrm{pH}$ as obtained under ambient air and pressure) showed no significant effect of either $\mathrm{NaCl}$ or $\mathrm{NaNO}_{3}$ up to at least $0.5 \mathrm{M},{ }^{[42]}$ in agreement with our data. The amount of water solely depends on the length of the alkyl chain on the imidazolium cation and the trend is in line with the increasing hydrophobicity of the successive ILs composed of $\mathrm{C}_{1} \mathrm{C}_{\mathrm{n}} \mathrm{im}^{+}$and $\mathrm{Tf}_{2} \mathrm{~N}^{-}$.

Second, it is important to note that the changes in $\mathrm{pD}$ values, as illustrated in Fig. 2 concerns rather small $\mathrm{D}^{+}$quantities: changes above $\mathrm{pD}_{\text {in }}=2$ mean that the involved $\mathrm{D}^{+}$ amounts are below ca. $5 \times 10^{-3} \mathrm{M}$. This value has to be compared to the larger amounts of sodium salts we used, in the range of $0.1-0.4 \mathrm{M}$ (one to two orders of magnitude above the $\mathrm{D}^{+}$values). Furthermore, the $\mathrm{D}^{+}$values of concern in this work are within or below the experimental uncertainties on $\mathrm{C}_{1} \mathrm{C}_{\mathrm{n}} \mathrm{im}^{+}$and $\mathrm{Tf}_{2} \mathrm{~N}^{-}$: therefore, it is not possible, for the data of this work to determine which species compensate for the $\mathrm{D}^{+}$depletion in the upper phase.

Let us now consider the $\left[\mathrm{Tf}_{2} \mathrm{~N}^{-}\right]_{\mathrm{u}}$ and $\left[\mathrm{C}_{1} \mathrm{C}_{\mathrm{n}} \mathrm{im}^{+}\right]_{\mathrm{u}}$ data in the absence of sodium perchlorate. As is evident from Table 1, the equilibrium values of $\mathrm{Tf}_{2} \mathrm{~N}^{-}$and $\mathrm{C}_{1} \mathrm{C}_{\mathrm{n}} \mathrm{im}^{+}$match perfectly, within experimental uncertainties. Therefore, although no attempts were made to determine the equilibrium values of the acid/sodium counter-anion $\left(\mathrm{Cl}^{-}\right.$or $\left.\mathrm{NO}_{3}{ }^{-}\right)$, we can reasonably 
assume that the transfer of $\mathrm{D}^{+}$, as observed in Fig. 2, is compensated by the joint transfer of either $\mathrm{NO}_{3}{ }^{-}$or $\mathrm{Cl}^{-}$. It should be recalled, nevertheless, that such low amounts will be very difficult to detect by any analytical means.

The situation is markedly different in the presence of increasing amounts of sodium perchlorate. It is obvious from Table 1 that the changes in $\mathrm{Tf}_{2} \mathrm{~N}^{-}$are no longer compensated by changes in $\mathrm{C}_{1} \mathrm{C}_{\mathrm{n}} \mathrm{im}^{+}$concentrations. Differences in aqueous solubilities of ILs' components have already been observed by other authors. For example, $\mathrm{C}_{1} \mathrm{C}_{4} \mathrm{im}^{+}$and $\mathrm{Cl}^{-}$do not solubilize equally in an aqueous phase containing potassium phosphate. ${ }^{[46]}$ In another paper, tributylammonium and bromide are shown not to dissolve similarly in an aqueous phase containing ammonium sulphate. ${ }^{[47]}$ To our opinion, such data are quite scarce in the literature for two main reasons. First, precise and efficient analytical methods are requested, owing to the complexity of the aqueous phases to be scrutinized. Second, and most importantly, many authors a priori assume an identical solubility of both ILs' components and consequently only measure one of the two ions. This is typically exemplified in the work of Freire and coworkers, ${ }^{[42]}$ in which the authors state that "no speculations about possible ion-exchange mechanisms will be carried". Under such a paradigm, it is clearly useless to measure both the cation and the anion solubilities. We are therefore in perfect agreement with the following comment of Freire et al., pointing that "a complete understanding of the ions partitioning process in those systems is of major importance". ${ }^{[42]}$

Only a limited comparison between Freire's data and ours can be made, because common salts between the two studies are restricted to $\mathrm{NaCl}$ and $\mathrm{NaNO}_{3}$, while $\left[\mathrm{C}_{1} \mathrm{C}_{4} \mathrm{im}\right]\left[\mathrm{Tf}_{2} \mathrm{~N}\right]$ is the only IL they investigated. On another hand, the salt concentration range they used is wider. Despite this limited experimental overlap one of the most important conclusions of Freire's work perfectly matches our results: $\mathrm{C}_{1} \mathrm{C}_{4} \mathrm{im}^{+}$solubility in the aqueous phase is strongly dependent on the nature and concentration of the salt present in the aqueous phase. More precisely, these authors observed that keeping the same cation (e.g. $\mathrm{Na}^{+}$), different anions $\left(\mathrm{Cl}^{-}, \mathrm{SO}_{4}{ }^{2-}, \mathrm{PO}_{4}{ }^{3-}\right.$ etc.) induce different $\mathrm{C}_{1} \mathrm{C}_{4}$ im ${ }^{+}$solubilities and, conversely, keeping the same anion (e. g. $\left.\mathrm{Cl}^{-}\right)$, different cations $\left(\mathrm{Na}^{+}, \mathrm{Li}^{+}, \mathrm{K}^{+}\right.$etc.) lead to different $\mathrm{C}_{1} \mathrm{C}_{4} \mathrm{im}^{+}$solubilities as well. Interestingly enough, the authors indicate that $\mathrm{NaCl}$ has only "marginal effects" on the solubility of $\mathrm{C}_{1} \mathrm{C}_{4} \mathrm{im}^{+}$. Whether this insignificant effect is due to compensations between salting-in and salting-out impact of $\mathrm{Na}^{+}$and $\mathrm{Cl}^{-}$respectively (or viceversa) or simply to no effect at all of both ions remains unresolved. Despite this pending question, their general conclusion on specific impact of salt cations and anions, and of limited effect of $\mathrm{NaCl}$ as such, are in perfect agreement with our data. This specific effect can be modulated by changing salt concentrations. From our experimental investigation, we confirm and extend this point for perchlorate addition, which was not studied in the paper by Freire and co-workers. ${ }^{[42]}$ Finally, Freire's data show that $\mathrm{NaNO}_{3}$ addition does not strongly impact $\mathrm{C}_{1} \mathrm{C}_{4} \mathrm{im}^{+}$solubility up to $0.5 \mathrm{M}$, in accord with our limited study up to $0.1 \mathrm{M}$.

On this basis, we note that if both anions and cations have rather different effects onto $\mathrm{C}_{1} \mathrm{C}_{4} \mathrm{im}^{+}$solubilities, it would thus be rather logical that, conversely (in other words, viceversa), $\mathrm{C}_{1} \mathrm{C}_{4} \mathrm{im}^{+}$and $\mathrm{Tf}_{2} \mathrm{~N}^{-}$would have specific effects onto any other salt component solubilities. This reasoning leads to possible differences between $\mathrm{C}_{1} \mathrm{C}_{4} \mathrm{im}^{+}$and $\mathrm{Tf}_{2} \mathrm{~N}^{-}$ solubilities in our mixtures and, by extension, between $\mathrm{C}_{1} \mathrm{C}_{\mathrm{n}} \mathrm{im}^{+}, \mathrm{Tf}_{2} \mathrm{~N}^{-}$and all other ions present in the mixtures. Differences between $\mathrm{C}_{1} \mathrm{C}_{4} \mathrm{im}^{+}$and $\mathrm{Tf}_{2} \mathrm{~N}^{-}$solubilities are actually what we observe. We would thus postulate that solubility differences are a general rule in these complex salt mixtures. In this frame, the low impact of $\mathrm{NaCl}$ would appear an exception rather than a common feature.

Turning back to our data, in the upper phase, charge balance should be written as:

$\left[\mathrm{D}^{+}\right]_{\mathrm{u}}+\left[\mathrm{C}_{1} \mathrm{C}_{\mathrm{n}} \mathrm{im}^{+}\right]_{\mathrm{u}}+\left[\mathrm{Na}^{+}\right]_{\mathrm{u}}=\left[\mathrm{OD}^{-}\right]_{\mathrm{u}}+\left[\mathrm{Tf}_{2} \mathrm{~N}^{-}\right]_{\mathrm{u}}+\left[\mathrm{ClO}_{4}^{-}\right]_{\mathrm{u}}$ 
Where all concentrations are equilibrium ones. As already emphasized, the amount of $\mathrm{OD}^{-}$ can be safely neglected in all samples. Let us consider the case of $\left[\mathrm{NaClO}_{4}\right]_{\text {in }}=0.4 \mathrm{M}$ : it is clear that the observed difference between $\left[\mathrm{Tf}_{2} \mathrm{~N}^{-}\right]_{\mathrm{u}}$ and $\left[\mathrm{C}_{1} \mathrm{C}_{4} \mathrm{im}^{+}\right]_{\mathrm{u}}$, which amounts to $42 \mathrm{mM}$ (Table $1, \mathrm{n}=4$ and 2) and indicates a depletion in positively charged species, cannot be compensated by $\mathrm{D}^{+}$transfers, for three main reasons: i) the total amount of $\mathrm{D}^{+}$in the system is significantly below the missing amount ii) data in Fig. 2 are indicative of a transfer from the upper to the lower phase, thus worsening the depletion in positively charged species in the upper phase and iii) $\mathrm{pD}$ in has no significant influence on $\mathrm{Tf}_{2} \mathrm{~N}^{-}$and $\mathrm{C}_{1} \mathrm{C}_{4}$ im ${ }^{+}$equilibrium values (Figs. 5, 8 and Suppl. Mat.). Therefore, neglecting the contributions of $\mathrm{OD}^{-}$and $\mathrm{D}^{+}$in eq. 1 , we derive for $\mathrm{n}=4$ or $\mathrm{n}=2$ and $\left[\mathrm{NaClO}_{4}\right]_{\text {in }}=0.4 \mathrm{M}$ :
$\left[\mathrm{Na}^{+}\right]_{\mathrm{u}}=\left[\mathrm{ClO}_{4}^{-}\right]_{\mathrm{u}}+0.042$ (in $\left.\mathrm{M}\right)$
$(\mathrm{n}=4)$
$\left[\mathrm{Na}^{+}\right]_{\mathrm{u}}=\left[\mathrm{ClO}_{4}^{-}\right]_{\mathrm{u}}+0.040$ (in M)
$(\mathrm{n}=2)$

It is thus evident that anion exchange occurs between $\left[\mathrm{Tf}_{2} \mathrm{~N}^{-}\right]_{\ell}$ and $\left[\mathrm{ClO}_{4}{ }^{-}\right]_{\mathrm{u}}$ anions during the equilibrium process. With an increase of the anions' radius in the order $\mathrm{Cl}^{-}<\mathrm{NO}_{3}{ }^{-}$ $<\mathrm{ClO}_{4}^{-}$, the free hydrogenation energy of the acids decreases $(\Delta \mathrm{G})$ which facilitates the transition into the organic phase, while protonation of $\left[\mathrm{Tf}_{2} \mathrm{~N}^{-}\right]$in the aqueous phase is not a major reaction as already noted by Jensen et al. because of its low $\mathrm{p} K_{\mathrm{a}}, 1.2 .^{[23]}$ This in turn causes the change of anion of the IL salt to a rather limited extent. This does not hampers the possibility that equal amounts of $\mathrm{Na}^{+}$and $\mathrm{ClO}_{4}{ }^{-}$ions transfer together to the lower phase, in addition to the specific exchange between $\mathrm{Tf}_{2} \mathrm{~N}^{-}$and $\mathrm{ClO}_{4}{ }^{-}$. As already anticipated by others, ${ }^{[48]}$ our data, evidencing an intricate interplay between mutual solubilities of all ions present demonstrate that biphasic systems of this kind have more profound connections with aqueous biphasic systems than could be thought at first glance.

The fact that the effects observed here are due to $\mathrm{ClO}_{4}{ }^{-}$rather than to $\mathrm{Na}^{+}$could also be deduced from the comparison with the $\mathrm{DCl}+\mathrm{NaCl}$ data, for instance. Experimental results by Gaillard et al. ${ }^{[49]}$ have already evidenced that aqueous solutions containing large amounts (in the molar range, from $0.5 \mathrm{M}$ to $6 \mathrm{M}$ ) of perchloric acid, when contacted with $\left[\mathrm{C}_{1} \mathrm{C}_{4} \mathrm{im}\right]\left[\mathrm{Tf}_{2} \mathrm{~N}\right]$ behave somewhat differently from others, containing nitric, hydrochloric and perrhenic acids.

Attempts to understand, at a molecular/ionic level, the solvation of the two components of $\left[\mathrm{C}_{1} \mathrm{C}_{4} \mathrm{im}\right]\left[\mathrm{Tf}_{2} \mathrm{~N}\right]$ in aqueous solutions containing sodium perchlorate and sodium chloride have been performed by use of molecular dynamics (DM) ${ }^{[50]}$ However, comparisons between our experimental data and these DM results should be made with caution for the following reasons: i) These calculations have been performed for an IL concentration of $0.1 \mathrm{M}$ and salt concentrations in the range $0.2 \mathrm{M}-2 \mathrm{M}$. These concentrations values are more or less out of the range of chemical conditions we investigated. ii) Calculations have been performed for an identical number of $\mathrm{C}_{1} \mathrm{C}_{4} \mathrm{im}^{+}$and $\mathrm{Tf}_{2} \mathrm{~N}^{-}$ions in water, which is very different from our case. On the one hand, DM results evidence a marked difference between $\mathrm{Cl}^{-}$and $\mathrm{ClO}_{4}{ }^{-}$in terms of organization of the salt ions around the IL cation and anion, which is in line with our data evidencing differences between these two salts in terms of individual solubilities of $\mathrm{C}_{1} \mathrm{C}_{\mathrm{n}} \mathrm{im}^{+}$and $\mathrm{Tf}_{2} \mathrm{~N}^{-}$. On the other hand, it is important to stress that the DM results are obtained for rather large salt concentrations, indeed favoring salt association (e.g. $\mathrm{ClO}_{4}{ }^{-}$and $\mathrm{C}_{1} \mathrm{C}_{4} \mathrm{im}^{+}$). The authors thus conclude on a direct binding of $\mathrm{ClO}_{4}{ }^{-}$ and $\mathrm{C}_{1} \mathrm{C}_{4} \mathrm{im}^{+}$as being the major reason for salting-in effects that remain to be experimentally observed. Under our chemical conditions, binding is unlikely to occur and we do not observe salting-in effect of $\mathrm{ClO}_{4}{ }^{-}$. To our opinion, understanding of the fundamental reasons of the variations we observed is out of the scope of this experimental work and we will therefore limit ourselves to some general considerations. Our data demonstrate that the notion of IL solubility, for which IL would be considered as a unique entity, is incorrect. One should rather take into account individual ionic solubilities in such complex mixtures composed of water, 
salts, acids and ILs. Using equilibrium formalism (that may not be fully appropriate anyhow), this should be accounted for as:

$$
\mathrm{H}_{\mathrm{u}}^{+}+\mathrm{Na}_{\mathrm{u}}^{+}+\mathrm{ClO}_{4}^{-} \mathrm{u}+\mathrm{C}_{1} \mathrm{C}_{\mathrm{nim}}{ }_{\mathrm{u}}^{+}+\mathrm{Tf}_{2} \mathrm{~N}_{\mathrm{u}}^{-} \leftrightarrows \mathrm{H}^{+}{ }_{\ell}+\mathrm{Na}^{+}{ }_{\ell}+\mathrm{ClO}_{4}{ }^{-}{ }_{\ell}+\mathrm{C}_{1} \mathrm{C}_{\mathrm{n}} \mathrm{im}^{+}{ }_{\ell}+\mathrm{Tf}_{2} \mathrm{~N}_{\ell}^{-}
$$

From this equation, it is clear that any attempt to describe our results on the basis of solubility products is most probably doomed to failure.

We now turn to the possible consequences our findings have onto the efficiency of the extraction process of metallic ions by ILs of the type studied. First, it is well-known that large amounts of water dissolving in IL (i.e. the lower phase, in our experiments) modify the density and viscosity of that phase which presumably plays a key role in assisted ion extraction $^{[51,52]}$ but this is not the only effect to be accounted for. Many experimental studies ${ }^{[5,}$ ${ }^{53-56]}$ have clearly demonstrated that cation exchange is quite a common extraction mechanism in ILs. Typically, extraction proceeds as:

$\mathrm{Ln}^{3+}{ }_{\mathrm{aq}}+\mathrm{S}_{\mathrm{IL}}+3 \mathrm{C}_{1} \mathrm{C}_{4} \mathrm{im}^{+}{ }_{\mathrm{IL}} \leftrightarrow[\mathrm{LnS}]^{3+}{ }_{\mathrm{IL}}+3 \mathrm{C}_{1} \mathrm{C}_{4} \mathrm{im}^{+}{ }_{\mathrm{aq}}$

Where $\mathrm{S}$ is any neutral ligand (calixarene, CMPO, crown-ether etc.)

Other studies have evidenced extraction mechanisms based on anionic exchanges. For example, studies of $\mathrm{Ln}^{3+}$ extraction to $\left[\mathrm{C}_{1} \mathrm{C}_{4} \mathrm{im}^{+}\right]\left[\mathrm{Tf}_{2} \mathrm{~N}^{-}\right]$using high HTTA concentrations (2thenoyltrifluoroacetone, an acidic extractant) revealed the existence of anionic tetrakis complexes in the IL phase as $\left[\mathrm{C}_{1} \mathrm{C}_{4} \mathrm{im}^{+}\right]\left[\operatorname{Ln}(\mathrm{TTA})_{4}{ }^{-}\right] \cdot{ }^{[48]}$ In this case, the extraction of anionic complexes is possible by the transfer of the $\left[\mathrm{Tf}_{2} \mathrm{~N}^{-}\right]$anions into the aqueous phase as:

\section{$\mathrm{Ln}^{3+}{ }_{\text {aq }}+4 \mathrm{HTTA}_{\mathrm{IL}}+\left[\mathrm{C}_{1} \mathrm{C}_{4} \mathrm{im}^{+}\right]\left[\mathrm{Tf}_{2} \mathrm{~N}^{-}\right]_{\mathrm{IL}}\left[\mathrm{C}_{1} \mathrm{C}_{4} \mathrm{im}^{+}\right]\left[\mathrm{Ln}(\mathrm{TTA})_{4}\right]_{\mathrm{IL}}+4 \mathrm{H}^{+}{ }_{\mathrm{aq}}+\left[\mathrm{Tf}_{2} \mathrm{~N}^{-}\right]_{\mathrm{IL}}$ (II)}

Such cationic (anionic) mechanisms have been demonstrated through the addition of the IL cation (anion) as its chloride salt (lithium salt) to the upper phase, ${ }^{[57-59]}$ which induces a decrease in the distribution ratio, as described through eq (I) (eq. II, respectively). More recently, another way to modify the equilibrium amounts of the IL cation (anion) has been evidenced: addition of large amounts of the IL anion, as its lithium salt, leads to a drop in IL's cation, as a consequence of solubility products. ${ }^{[20]}$ Conversely, adding chloride salts of the IL's cation decreases the equilibrium amount of the IL's anion in the upper phase. Such external changes in either the IL's cation or anion have obvious consequences in terms of distribution ratio, according to eqs. I or II, as calculated ${ }^{[20]}$ and as experimentally observed for Ln and other metallic ions. ${ }^{[60,61]}$ Our data evidence a third way to play on the distribution ratio values: adding sodium perchlorate salt does change the equilibrium values of either $\mathrm{C}_{1} \mathrm{C}_{\mathrm{n}} \mathrm{im}^{+}$ or $\mathrm{Tf}_{2} \mathrm{~N}^{-}$: By doing so, we expect increase in $\mathrm{D}$ ratio provided the extraction mechanism is ruled by eq. I and we predict a decrease in D for anionic exchange (eq. II). Moreover, based on this observation, we expect great differences in $\mathrm{D}$ values by simply replacing nitric acid by perchloric acid in liquid/liquid extraction of metallic ions towards IL phases, all other chemical aspects being equal. Similarly, caution should be paid to experimental results arising from samples containing large amounts of perchloric acid/perchlorate salts. ${ }^{[48]}$ Specific studies on these two aspects are currently under progress.

\section{Conclusions}

There are several reports in literature describing the mutual solubilities of water and ILs ${ }^{[20,29]}$ but to the best of our knowledge, a profound and methodical Q-NMR study was missing. We have thus performed a detailed Q-NMR study aiming at the determination of the quantity of both IL cations and anions transferred in the upper phase of biphasic systems based on aqueous solutions and ionic liquids because mutual solubility data constitute a necessary step to assess and control the environmental impact of ILs in aquatic systems prior to their applications. ${ }^{[29]}$ 
We have evidenced a very different impact on mutual solubilities $\left(\mathrm{D}^{+}, \mathrm{C}_{1} \mathrm{C}_{\mathrm{n}} \mathrm{im}^{+}\right.$and $\mathrm{Tf}_{2} \mathrm{~N}^{-}$) of perchlorate ions as compared to nitrate and chloride already at $0.1 \mathrm{M} \mathrm{NaClO}_{4} v s$ $\mathrm{NaCl}$ or $\mathrm{NaNO}_{3}$. The results of the present work have important consequences on several aspects in fundamental, analytical, applied and environmental chemistry.

First, when determining the composition of aqueous biphasic systems based on ILs, caution should be paid to charge balance, as evidenced in our work: it is not enough to measure the distribution of one of the IL's component between the upper and lower phase to be assured of the distribution of the IL's counter-anion and this precautionary principle should also apply to any of the constituents of such mixtures.

Second, on a practical/industrial viewpoint, do intricate solubilisation phenomena, as evidenced in our work, totally hamper the application of ILs for liquid-liquid extraction processes? Obviously, the answer can only be derived from a minute balance between all aspects: ILs are known to tremendously increase extraction efficiencies, which represents a clear benefit, not only in terms of money but also in terms of ecological efficiency. Although liable to leakeage in aqueous phases, which is an obvious disadvantage in terms of profits, not all ILs are highly toxic and a common scale able to account for all these very different pros and cons is the basis on which an answer could be given. This is clearly out of the scope of the present work. We will limit ourselves to note that ILs appear in an increasing number of studies suggesting separation processes based on ILs for precious metals, such as radioactive ones ${ }^{[62]}$ or those from the platinoïd group. ${ }^{[63-65]}$ This is a strong indication that ILs have at minimum, a niche to occupy in liquid/liquid extraction of metals.

Finally, on an environmental perspective, it is thus not enough to conclude that increasing the length of the alkyl chains of 1-alkyl-3-methylimidazolium cations, the undesirable IL's component solubilities, which have typically been found to have a pronounced impact on metal extraction efficiency, can be successfully reduced. That ILs can be rendered "greener" simply by increasing their cation hydrophobicity is not perfectly true, and the remarkable aqueous solubility of IL's anion under some of the chemical conditions of this work definitely questions the weak environmental footprint of ILs. Furthermore, considering the differences between ILs' cation and anion solubility, it is also questionable to define an IL solubility value. Thus experiments studying ILs' toxicity should clearly make a distinction between the cation and anion properties in that respect.

\section{Acknowledgements}

The authors are grateful to FP7-PEOPLE-Marie Curie Actions-IEF for the financial support of the project INNOVILLN (622906) 2014-2016. The research in this paper was supported in part by the University of Strasbourg Institute for Advanced Study (USIAS) as part of a USIAS Fellowship. The help of Dr Bruno Vincent and Dr Maurice Coppe (NMR Centre at the Chemical Faculty of the Strasbourg University) for the NMR measurements of this work is greatly acknowledged. We also thank the three-year undergraduate student Desislava Gerginova (UCTM) for assistance.

Electronic Supplementary Information (ESI) available: Chemical structures of ILs (Scheme S-

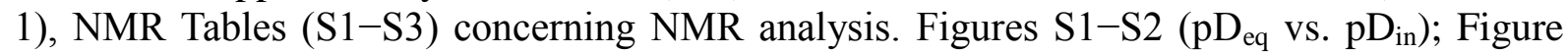
S3: $\mathrm{D}_{2} \mathrm{O}$ amount absorbed by IL phase $\mathrm{n}=6,8$ and 10; Figures $\mathrm{S} 4-\mathrm{S} 6\left[\mathrm{Tf}_{2} \mathrm{~N}^{-}\right]$data $(\mathrm{n}=6,8$ and 10); Fig. $S 7\left[\mathrm{C}_{1} \mathrm{C}_{\mathbf{n}} \mathrm{im}^{+}\right]$data $\mathrm{n}=4$. This material is available free of charge via the Internet at http://...; 


\section{References}

[1] S. Wellens, B. Thijs, K. Binnemans, Green Chem., 2012 14, 1657-1665.

[2] S. Wellens, R. Goovaert, C. Moller, J. Luyten, B. Thijs, K. Binnemans, Green Chem., 2013 15, 31603164.

[3] Ionic Liquids: Theory, Properties, New Approaches, InTech, 2011.

[4] P. Wasserscheid, T. Welton, lonic liquids in synthesis, Wiley-VCH, Weinheim, 2008.

[5] I. Billard, lonic liquids: new hopes for efficient lanthanide/actinide extraction and separation?, in: J.C.G. Bünzli, V.K. Percharsky (Eds.) Handbook on the Physics and Chemistry of Rare earth, Elsevier, 2013.

[6] P. Sun, D.W. Armstrong, Anal. Chim. Acta, 2010 661, 1-16.

[7] T.D. Ho, C. Zhang, L.W. Hantao, J.L. Anderson, 2014 86, 262-285.

[8] H. Passos, M.G. Freire, J.A.P. Coutinho, Green Chem., 2014 10.1039/C4GC00236A.

[9] I. Billard, A. Ouadi, C. Gaillard, Anal. Bioanal. Chem., 2011 400, 1555-1566.

[10] Chun, S., Dzyuba, S. V., Bartsch, R. A., Adams, M., Anal. Chem., 2001 73, 3737.

[11] H. Okamura, A. Ohno, T. Saito, N. Aoyagi, H. Nagawana, Anal. Chem., 2012 84, 9332-9339.

[12] J.M. Reyna-Gonzales, A.A.J. Torriero, A.I. Siriwardana, I.M. Burgar, A.M. Bond, Anal. Chem., 2010 82, 7691-7698.

[13] T.J. Stockmann, J. Zhang, A.M. Montgommery, Z. Ding, Anal. Chim. Acta, 2010 821, 41-47.

[14] K. Binnemans, Chem. Rev., 2007 107, 2592.

[15] X. Sun, H. Luo, S. Dai, Talanta, 2012 90, 132-137.

[16] H. Okamura, H. Takagi, T. Isomura, K. Morita, H. Nagatani, H. Imura, Anal. Sci., 2014 30, 323325.

[17] I. Billard, A. Ouadi, C. Gaillard, Dalton Trans., 2013 42, 6203-6212.

[18] A. Ouadi, O. Klimchuk, C. Gaillard, I. Billard, Green Chem., 2007 9, 1160.

[19] I. Billard, A. Ouadi, E. Jobin, J. Champion, C. Gaillard, S. Georg, Solv. Ext. Ion Exchange, 201129 , 577-601.

[20] V. Mazan, I. Billard, N. Papaiconomou, RSC Advances, 2014 4, 13371-13384.

[21] A. Rout, J. Kotlarska, W. Dehaen, K. Binnemans, Phys. Chem. Chem. Phys., 2013 15, 1653316541.

[22] M. Sypula, A. Ouadi, C. Gaillard, I. Billard, RCS Advances, 2013 3, 10736-10744. 
[23] M.P. Jensen, J. Neuefeind, J.V. Beitz, S. Skanthakumar, L. Soderholm, J. Am. Chem. Soc., 2003 125, 15466-15473.

[24] A. Spietelun, L. Marcinkowski, M.d.I. Guardia, J. Namiesnik, Talanta, 2014 119, 34-45.

[25] D. Zhao, Y. Liao, Clean, 2007 35, 42-48.

[26] R.F.M. Frade, C.A.M. Afonso, Hum. Exp. Toxicol. , 2010 29, 1038-1054.

[27] S.P. Costa, V.D. Justina, K. Bica, M. Vasiloiu, P.C. Pinto, M.L. Saraiva, J Hazard Mater. , 2014 265, 133-141.

[28] Z. Kolarik, Solv. Ext. Ion Exchange, 2013 31, 24-60.

[29] M.G. Freire, P.J. Carvalho, R.L. Gardas, I.M. Marrucho, L.M.N.B.F. Santos, J.A.P. Coutinho, J. Phys. Chem. B, 2008 112, 1604-1610.

[30] A. Latala, M. Nedzi, P. Stepnowski, Green Chem., 2009 11, 1371-1376.

[31] S. Stolte, M. Matzke, J. Arning, A. Boschen, W.R. Pitner, U. Welz-Biemann, B. Jastorff, J. Ranke, Green Chem., 2007 9, 1170-1179.

[32] C. Pretti, C. Chiappe, D. Pieraccini, M. Gregori, F. Abramo, G. Monni, L. Intorre, Green Chem., $20068,238-240$.

[33] M. Matzke, S. Stolte, K. Thiele, T. Jufferholz, J. Arning, J. Ranke, U. Wels-Biemann, B. Jastorff, Green Chem., 2007 9, 1198-1207.

[34] J. Ranke, K. Molter, F. Stock, U. Bottin-Weber, J. Poczobutt, J. Hoffmann, B. Ondruschka, J. Filser, B. Jastorff, Ecotox. Environ. Safety, 2004 58, 396-404.

[35] K.M. Docherty, S.Z. Hebbeler, C.F. Kulpa, Green Chem., 2006 8, 560-567.

[36] M. Dietz, J.A. Dzielawa, Chem. Commun., 20012124.

[37] F. Xie, T.A. Zhang, D. Dreisinger, F. Doyle, Minerals Engineering, 2014 56, 10-28.

[38] I. Billard, S. Georg, Helv. Chim. Acta, 2009 92, 2227-2237.

[39] F.A. Deeney, J.P. O'Leary, Eur. J. Phys., 2009 30, 871-876.

[40] M. Atanassova, I. Billard, J. Sol. Chem., 2014 in press.

[41] T.J. Bell, Y. Ikeda, Dalton Trans., 2011 40, 10125-10130.

[42] M.G. Freire, P.J. Carvalho, A.M.S. Silva, L.M.N.B.F. Santos, L.P.N. Rebelo, I.M. Marrucho, J.A.P. Coutinho, J. Phys. Chem. B, 2009 113, 202-211.

[43] K. Rehac, P. Moravek, M. Strejc, Fluid Phase Equilibria, 2012 316, 17-25.

[44] F.M. Maia, O. Rodriguez, E.A. Macedo, J. Chem. Thermodynamics, 2012 48, 221-228.

[45] S. Katsuta, K. Nakamura, Y. Kudo, Y. Takeda, J. Phys. Chem. B, 2012 116, 852-859. 
[46] K.E. Gutowski, G.A. Broker, H.D. Willauer, J.G. Huddleston, R.P. Swatloski, J.D. Holbrey, R.D. Rogers, J. Am. Chem. Soc., 2003 125, 6632.

[47] Y. Akama, M. Ito, S. Tanaka, Talanta, 2000 53, 645-650.

[48] M.P. Jensen, M. Borkowski, I. Lazak, J.V. Beitz, P.G. Rickert, M.L. Dietz, Sep. Sci. Technol., 2012 47, 233-243.

[49] C. Gaillard, V. Mazan, S. Georg, O. Klimchuk, M. Sypula, I. Billard, R. Schurhammer, G. Wipff, Phys. Chem. Chem. Phys., 2012 14, 5187-5199.

[50] M.G. Freire, C.M.S.S. Neves, A.M.S. Silva, L.M.N.B.F. Santos, I.M. Marrucho, L.P.N. Rebelo, J.K. Shah, E.J. Maginn, J.A.P. Coutinho, J. Phys. Chem. B, 2010 114, 2004-2014.

[51] A. Chaumont, G. Wipff, Inorg. Chem., 2004 43, 5891-5901.

[52] S.L. Garvey, C.A. Hawkins, M.L. Dietz, Talanta, 2012 95, 25-30.

[53] M. Atanassova, V. Kurteva, L. Lubenov, I. Billard, RSC Advances, 2014 4, 38820-38829.

[54] A. Stojanovic, B.K. Keppler, Sep. Sci. Technol., 2012 47, 189-203.

[55] Y. Shen, X. Tan, L. Wang, W. Wu, Sep. Pur. Technol., 2011 78, 298-302.

[56] K. Takao, T.J. Bell, Y. Ikeda, Inorg. Chem., 2013 52, 3459-3472.

[57] K. Nakashima, F. Kubota, T. Maruyama, M. Goto, Ind. Eng. Chem. Res., 2005 44, 4368.

[58] X. Sun, D. Wu, J. Chen, D. Li, J. Chem. Technol. Biotechnol., 2007 82, 267.

[59] K. Shimojo, K. Kurahasha, H. Naganawa, Dalton Trans., 20085083.

[60] T.X. Sun, X.H. Shen, Q.D. Chen, Sci. China, Chem., 2013 56, 782-788.

[61] M. Bonnaffé-Moity, A. Ouadi, V. Mazan, S. Miroshnichenko, D. Ternova, S. Georg, M. Sypula, C. Gaillard, I. Billard, Dalton Trans., 2012 41, 7526-7536.

[62] I.A. Shkrob, T.W. Marin, M.P. Jensen, Ind. Eng. Chem. Res., 2014 53, 3641-3653.

[63] N. Papaiconomou, S. Génand-Pinaz, J.M. Leveque, Dalton Trans., 2013 42, 1979-1982.

[64] N. Papaiconomou, G. Vite, N. Goujon, J.M. Levêque, I. Billard, Green Chem., 2012 14, 2050-2056.

[65] N. Papaiconomou, I. Billard, E. Chainet, RSC Adavances, 2014. 
Graphical abstract:

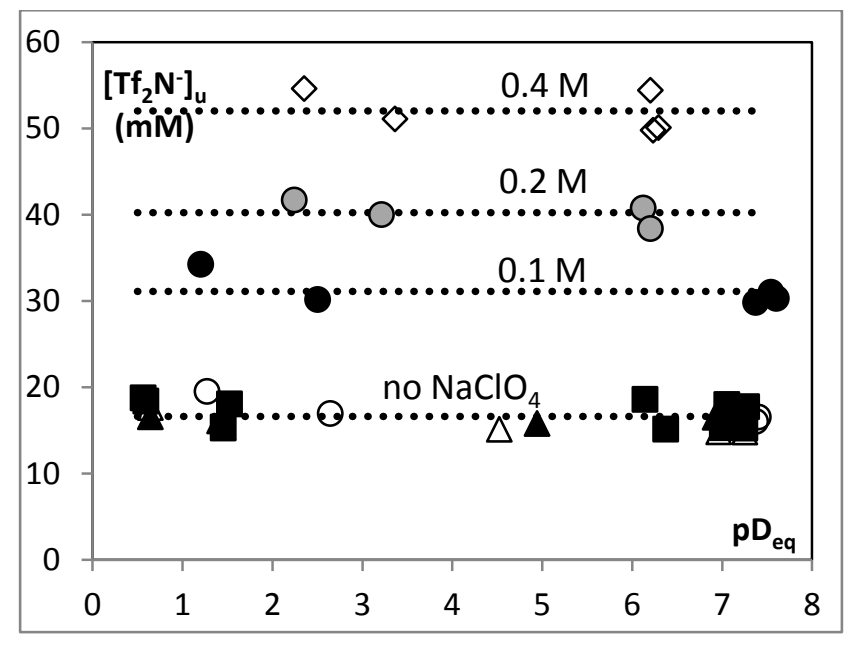

Addition of sodium perchlorate enhances ILs' anion solubility, while decreasing ILs' cation solubility to an slightly acidic aqueous phase. 